\title{
The Accreditation of Libraries and Library Schools
}

\author{
Mr. Kirkpatrick is librarian, University \\ of Utah.
}

A $\mathbf{S}$ MANY of you know, there has re1 cently been established a National Commission on Accrediting. A report on the activities of this body may be found in the 1950 Transactions and Proceedings of the National Association of State Universities. $^{2}$ The creation of this group gives library leaders a chance to express themselves with regard to the accrediting process. The I 949 volume of the same series contains an excellent historical outline of the good and bad tendencies of standardizing agencies.

Generally speaking, the virtues of these bodies are supposed to include high educational standards and adequately prepared practitioners. To attain these goals most bodies have fought for properly trained and treated teachers of would-be lawyers, foresters, social workers, doctors, engineers and the like. Logic is sound. Only a good lawyer can train good lawyers. Good lawyers come high-so do the others listed.

However, so far as library service goes, these groups have often insisted upon having a librarian set aside to serve them and have frequently hoped this librarian would be trained, but have never to my knowledge worried about the service load, the rank, the salary, the tenure or the study privileges of the bookman who serves them.

A few examples of the difference in ap-

\footnotetext{
1 Paper presented at the meeting of the University Libraries Section, A.C.R.L., January 30, 195 I, Chicago. ${ }^{2}$ National Association of State Universities in the U.S:A., Transactions and Proceedings. Harold Stoke, Louisiana State University, Baton Rouge, La., I949, I950.
}

proach to teachers and to librarians should suffice. The Society of American Foresters stipulated in the early 1930's that teachers of forestry should be good enough men to merit a salary a step or so above that for the entering grade of government service. In at least one school this meant forestry instructors started at a salary several hundred dollars above that paid other beginners. At the same time this group asked for a special library, with a librarian, but expressed no concern for either the salary or the training of the person picked to serve in that capacity.

More recently, we in $\mathrm{U}$ tah were visited by the American Council on Pharmaceutical Education. They looked over our divisional library which serves medicine, predental, nursing and pharmacy. Then the pharmacy staff insisted we designate one of the staff as pharmacy librarian. No advice was given as to rank or salary of such a librarian, but the teaching staff of the College of Pharmacy must include three full professors or there is no accredited status.

In 1949 the American Society for Engineering Education annoyed college presidents by asking how much law professors were being paid. Clearly, the intent was to guarantee as good, or at least as well-paid, engineering teachers. Noteworthy to librarians was the lack of concern as to how engineering and law librarians were being treated.

My point is simple. If there be any virtue in insisting upon well-trained, reasonably scheduled, securely placed and well- 
paid teachers in these fields, that same virtue should apply to special librarians. Since accrediting is peculiarly tied in with educational agencies, and since libraries are vital to all training programs, it is my hope that the American Library Association will offer to rate libraries and library positions for all accrediting agencies and to criticize for this new commission past practices in the rating of libraries.

As just noted, the virtues of these standardizing groups have not always reached those who work with books. This is not so of the known evils. Two apply particularly to special libraries. One is the urging of disproportionate expenditures for selected programs, and the other is judging the desirability of local administrative organization.

Here, again, it is easy to supply chapter and verse. A few cases should once more suffice. Even during the depression, the American Bar Association insisted upon a minimum book and periodical budget of $\$ 2000$ a year. At the university I represent this was as much as arts and sciences, social work, education, and business schools received combined. Furthermore, a special law librarian was demanded; but while the teachers all had the minimum rank of associate professor, the law librarian, with an LL.B. and B.L.S., was rated an instructor.

During the same period the American Medical Association visiting committee insisted upon a book budget of $\$ 700$ a year for medicine, but cared not a whit that basic biology was receiving only $\$ 120$ a year.

We have had pressure put on us for separate libraries for architecture, journalism, business and social work. All of you know of the difficulties which arise when a campuswide system of school and departmental libraries develops. More money goes for poorer service. More dollars must be spent for duplicate books and magazines. Here indeed we can rapidly come to a system of equality for none but special status for all.

Again, it would be my hope that the ALA take the opportunity afforded by a new committee to call for an examination of this cry for special book allotments and special college or departmental libraries.

Last of all, if the accrediting agencies are supposed to help insure a supply of properly trained workers, it might be well to ask what has happened in the field of school library work.

An examination of the Biennial Survey of Education reveals that three-fourths of the school libraries in America are manned by untrained personnel. I knew that in Utah, Nevada, Idaho and Wyoming the school librarians were not as well trained as were the school teachers. Apparently, the picture is nationwide. An economy of scarcity seems to be in operation.

When you look into teacher training, you find that virtually every teachers' college and university offers courses in those subjects considered basic in a modern school. A college without courses in chemistry, English or history would be laughed at. Yet, we claim the library is the heart of the school but are not even concerned that no courses are given in library work.

In Utah we were forced into librarycourse work by regional and state accrediting agencies. We began the work apologetically because all of the trained librarians in the state suspected ALA frowned on such courses. When the regional North Central representative asked about correspondence courses, we were even more positive that we were living in sin. Wheeler's report $^{3}$ on education for librarianship makes it crystal clear that ALA views home study, or learning by reading, with dark suspicion.

Wheeler, Joseph L. Progress and Problems in Education for Librarianship. New York, Carnegie Corporation of New York, I 946, p.84. 
Even so, we have given a course in school library methods to workers in Idaho, Nevada, California, Washington, Colorado, Nebraska, Kansas, Oklahoma, North Carolina, South Carolina, Mississippi, Missouri, Illinois and Texas. This would seem to reflect the nationwide lack of training among school librarians. We have fewer home study students from Utah because we give resident courses. We feel sure that the teacher-training agencies of these states must have missed an opportunity for service.

We hope the day will come when every first class teacher-training institution gives a major in library work. When young people can secure training for librarianship in the same length of time needed to become teachers, when they can do it in their own state or section of a state, and when this training is accepted as the basis for advanced work from one part of the country to another, then we will have our share of the best young students going into library work. If we want to see the day come when every school library is in the care of a trained librarian, some such realistic approach is necessary.

It seems likely this day will arrive sooner if ALA gets out of the accrediting field so far as school library work goes, and leaves this up to the regional agencies which pass on other questions of training for service in the public schools.

As it is, the situation of some of us is anomalous, to say the least. We explain to our students we are unaccredited by ALA, but our credits are accepted in most states for certification but not by library schools elsewhere. We then ask these same students to join our national organization. The answer of one farm girl is worth pondering:

"Mister, it sounds to me as if you were asking us to buy the front end of a cow."

\section{Libraries in an Irfflationary Cycle}

\section{(Continued frim page 342)}

In 1949 , the range was from $\$ 3800$ to $\$ 10,500$, with a median of $\$ 7000$. The increase of the medians was 55 per cent.

In teachers colleges the range was from $\$ 1400$ to $\$ 3750$ in 1939 , and from $\$ 2400$ to $\$ 6000$ in 1949 ; the median rose from $\$ 2200$ to $\$ 4250$, an increase of 93 per cent.

By reducing the proportion of professional workers, libraries have been able generally to keep salaries in pace with the cost of living, and in some cases to improve them. While figures on teaching salaries are not immediately available for the same institutions, it is probable that librarian salaries have been increased as much as their faculty colleagues' salaries have.

This situation is not one to be accepted as good; librarianship is still not one of the most lucrative, and often not as well paid as teaching.

In summary, the colleges and universities have been able thus far to survive the inflation by drawing on some of the accumulated book resources, by increasing the use of nonprofessional personnel. On the average, librarians' salaries have not absorbed the economies. How long they can continue to operate on reducing percentages of the educational budget is problematical. The book collections will soon become obsolete; the limits of replacing professional with nonprofessional staff will soon be reached; beyond that library service will suffer deterioration. 